DOI:http://dx.doi.org/10.24093/awejtls/vol1no2.7

\title{
Western Feminism or Return to Authentic Islam? Jordanian Women in Faqir's Pillars of Salt and My Name is Salma
}

\author{
Suaad Muhammad Alqahtani \\ Department of English Language, College of Arts \\ King Khalid University, Abha, Saudi Arabia
}

\begin{abstract}
This paper focuses on the violence against Jordanian women through Fadia Faqir's novels, Pillars of Salt and My Name is Salma. These novels question cultural conventions that tolerate men's oppression and killing of women in the name of the family's honour in most Arab countries. The analysis of the two novels illustrates how Faqir's opposition to women's subordination and victimisation in the name of Islam stems from her interest in going back to authentic teachings of Islam with regard to women, rather than Western feminist theories. In addition, the similarity between Orientalist misrepresentation of women's status in Islam and patriarchal misinterpretation of the Holy Qura'n and Prophet Muhammad's Sunnah to subordinate women is explored and examined from the postcolonial feminist critical perspective. This paper highlights feminist contribution to raising awareness about violence against women in some Arab countries through literature.
\end{abstract}

Keywords: counter narrative, feminism and Islam, honour crimes, orientalism, postcolonial feminism

Cite as: Alqahtani, S. M. (2017). Western Feminism or Return to Authentic Islam? Jordanian Women in Faqir's Pillars of Salt and My Name is Salma. Arab World English Journal for Translation \& Literary Studies, 1(2). DOI:http://dx.doi.org/10.24093/awejtls/vol1no2.7 